\title{
Marking 100 years since Rudolf Höber's discovery of the insulating envelope surrounding cells and of the $\beta$-dispersion exhibited by tissue
}

\author{
Ronald Pethig ${ }^{1,2}$ and Ilka Schmueser ${ }^{1}$ \\ 1. Institute for Integrated Micro and Nano Systems, School of Engineering, The University of Edinburgh, Edinburgh EH9 $3 J F$, UK \\ 2. E-mail any correspondence to: Ron.Pethig@ed.ac.uk
}

\begin{abstract}
Between 1910 and 1913 Rudolf Höber presented proof that the interiors of red blood cells and muscle cells contain conducting electrolytes, and that each conducting core is contained within an insulating membrane. He did this by demonstrating, in a series of remarkable electrical experiments, that the conductivity of compacted cell samples at low frequencies $(\sim 150 \mathrm{~Hz})$ was about ten-times less than the value obtained at $\sim 5 \mathrm{MHz}$. On perforation of the membrane, the low-frequency conductivity increased to a value approaching that exhibited at $\mathrm{MHz}$ frequencies. Apart from representing a major milestone in the development of cell biology and electrophysiology, Höber's work was the first description of what we now call the dielectric $\beta$-dispersion exhibited by cell suspensions and fresh tissue.
\end{abstract}

Keywords: Dielectric beta-dispersion; Cells; Erythrocytes, Membrane capacitance; Membrane resistance; Muscle cells; Tissue impedance.

\section{Introduction}

In a series of electrical experiments, performed between 1910 and 1913, Rudolf Höber provided the first evidence that cells possess a resistive dielectric membrane that surrounds a conducting electrolytic interior [1-3]. He determined that the conductivities of compacted red blood cells and frog muscle tissue measured at $\mathrm{MHz}$ frequencies were significantly higher than that measured at $\sim 150 \mathrm{~Hz}$. At low frequencies the current was deduced to flow around the cells, but that at high frequencies the current was able to penetrate into the conducting cell interior. The internal conductivity of a red blood cell was estimated to be about that of a $0.2 \% \mathrm{NaCl}$ solution. Confirmation that the $\mathrm{MHz}$ value represented the internal conductivity was obtained by inducing haemolysis (porating the envelope surrounding the interior) and then finding that the $\mathrm{MHz}$ conduction current remained almost unchanged, whereas the low-frequency conduction increased significantly. This was taken as evidence that the conducting interior of a red blood cell is contained within a resistive dielectric envelope. As such this represents a major milestone in the development of cell biology and electrophysiology. It is also a historic event for the subject of electrical bio-impedance because Höber's work was the first description of the dielectric $\beta$-dispersion exhibited by cell suspensions and fresh tissue (see Figure 1). The $\beta$-dispersion is basically a manifestation of the fact that a cell's outer membrane acts as a high resistance to direct current and low frequency alternating current, and also has a large capacity for accumulating ions at the membrane surface. The first studies of this are commonly attributed [4, p.162] to much later works, such as those of Fricke and co-workers $[5,6]$.

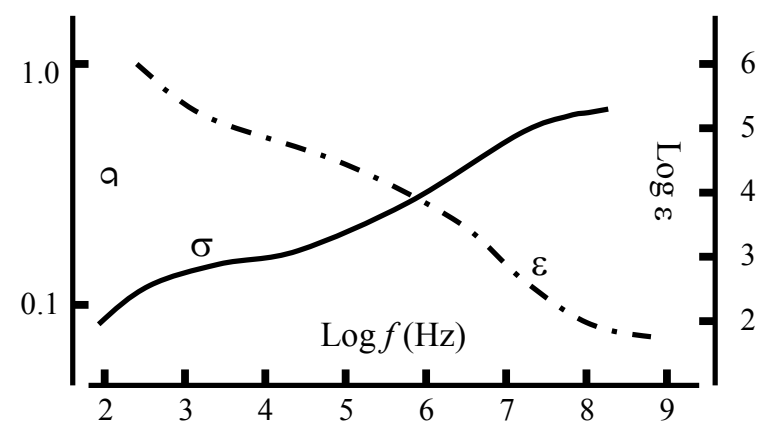

Figure 1: A schematic of the $\beta$-dispersion exhibited by fresh tissues and compacted viable cells (derived from Schwan [4]). As the frequency is increased from $\sim 1 \mathrm{kHz}$ to $100 \mathrm{MHz}$, this dispersion is characterised by about a five-fold increase of conductivity, and around three orders of magnitude decrease of permittivity $\varepsilon$.

In setting the scene for Höber's experiments we note that the scientific origins of electrophysiology go back to Galvani's experiments in the 1790's, followed by the careful advances made by Emil Du Bois-Reymond from 1848 to 1860 , which involved the study of the active electrical properties of cells and tissue. By active properties we mean the generation of electrical currents in tissues that are induced by their electrical stimulation or injury, the most well known example being the excitation and propagation of electrical impulses in nerves. Many studies in the field we term electrical bioimpedance are concerned with determining the passive electrical properties of cells and tissue, usually as a function of the frequency of an applied electrical field [7]. Höber's measurements of the passive conductivity of compacted blood corpuscles and of muscle tissue at low and high frequencies therefore mark the beginning of bioimpedance research. They were also an essential element in the development of electrophysiology particularly in elucidating nerve pulse propagation.

Höber would have known of the theories developed by Max Planck [8] and Walther Nernst [9]. Encompassed in what is still known as the Nernst-Planck equation, the cell membrane was envisaged to be a thin layer of non-aqueous electrolyte across which ions move into or out of a cell 
down concentration gradients and with an electric field. To quote Nernst [9]: "It is known that in organised tissue the contents of the aqueous solution that forms the electrolytic conductor is not equal everywhere, and in particular is different within and without cells. Equilibrium through diffusion is prevented by semipermeable membranes." Planck later founded quantum physics and was awarded the 1918 Nobel Prize in Physics, whilst Nernst is better known for developing the third law of thermodynamics and the Nernst equation widely used in electrochemistry, for which he was awarded the 1920 Nobel Prize in Chemistry. The first indications that the semipermeable membrane may consist of molecules such as lecithin and cholesterol located near the cell surface followed from the finding by Overton that many molecules penetrate into cells at a rate proportional to their lipid solubility [10]. Experiments, notably by Stewart [11], had also demonstrated the action of chemicals such as saponin in changing the structure of blood corpuscle membranes so as to release their internal pigments and salts. So, although the structure of a cell was completely unknown at the time, and in the absence of any evidence for the existence of an enveloping membrane, Bernstein was able in 1902 [12] to combine all of this information into his famous membrane hypothesis, consisting of three concepts:

i) Cells consist of a conducting electrolyte surrounded by a thin membrane that is largely impermeable to ions.

ii) In its resting state a difference in electrical potential exists across the membrane.

iii) On electrical stimulation of an excitable cell there is a transient increase of the membrane permeability towards potassium ions. This results in a significant reduction in the transmembrane potential difference, assumed to be the Nernst diffusion potential for potassium ions.

Höber's experiments [1-3] provided direct electrical evidence for the validity of Bernstein's first hypothesis. They proved the existence of an electrolytic cytoplasm containing free ions, and the implication of a thin, poorly conducting dielectric envelope (eine dielektrische Hülle), leading the way to the now accepted structural model of a cell and its outer membrane. His findings also provided an explanation for the long known fact that living tissue presents a high resistance to electrical current, but that after death this resistance becomes significantly reduced. Although Bernstein's third hypothesis subsequently required major revisions, for many years it provided a guiding principle that eventually led to the award of the 1963 Nobel Prize in Physiology or Medicine to Eccles, Hodgkin and Huxley "for their discoveries concerning the ionic mechanisms involved in excitation and inhibition in the peripheral and central portions of the nerve cell membrane".

\section{Höber's experiments: 1910 - 1912}

In the introduction to his 1910 paper [1] Höber comments on the fact that very little is known about the electrical conductivity of the inside of cells, and that this reflects an ignorance of the state of salts inside a cell. "If one measures the conductivity of corpuscles centrifuged from blood, they are found to be about 100-times less conductive than the plasma. However, if the corpuscles are destroyed with saponin, as described by Stewart, their conductivity increases rapidly over a few minutes, as if the electrolyte concentration has been raised 40- to 50-times. This is similar to what happens on tissue death. If one measures the electrical resistance of tissue, according to the well known method of Kohlrausch one finds that as long as it lives it presents the electrical current with a high resistance, whilst after death of the tissue the resistance drops significantly". He then suggests that this can be explained in one of two following ways:

i) The normal surface of the cell represents a dielectric envelope around electrolytic contents, and at death the electrical insulating properties of the envelope is lost, or

ii) In the action of death the previously bound electrolytes within the cell become free.

The stated objective of his 1910 paper was to show which of these two speculations was correct by devising, in accordance with the paper's title: "a method to measure the internal electrical conductivity of cells".

\section{Low Frequency Measurements (Kohlrausch's method)}

The basic method used by Höber to determine the conductivity of the cell samples at a low frequency (100 200 Hz) had been established some 40 years earlier by Kohlrausch and Nippoldt [13, 14] in their efforts to measure the electrical resistance of fluids, and to demonstrate that Ohm's law was applicable to electrolytes. Earlier efforts to do this were complicated by the effects of electrode polarisation, which Kohlrausch and Nippoldt overcame by increasing the effective electrode surface area (platinized platinum electrodes) and using an alternating current. The alternating current was generated by rotating a magnetic disk within an induction coil. In the first design the magnetic disk was attached to a siren and rotated by blowing air from a foot-powered fan at the siren. Later designs incorporated a hand-driven system of pulleys and gears, and later an electric motor, to drive the rotating magnet. The alternating current was inductively coupled to a Wheatstone bridge, in which a telephone replaced the galvanometer normally used to detect the balanced condition in a dc bridge. The measurement cell containing the test sample and a resistance box formed the two arms of the bridge, and the other two arms of the bridge contained a sliding contact along a metre wire (Kohlrausch slide-wire) until a minimum sound was heard in the telephone. 
Höber rinsed the red blood cells with isotonic sugar solution and then centrifuged them to obtain a highly compacted cell sample. He found that these samples exhibited a conductivity equivalent to that of a $0.02 \% \mathrm{NaCl}$ solution $(\sim 42 \mathrm{mS} / \mathrm{m})$ when measured at the low frequencies (100 200 Hz) available using Kohlrausch's method.

\section{Measurements at $\mathrm{MHz}$ Frequencies}

The circuit used by Höber to generate electrical oscillations and measure the conductivity of compacted blood cells at $\mathrm{MHz}$ frequencies is shown in Figure 2.
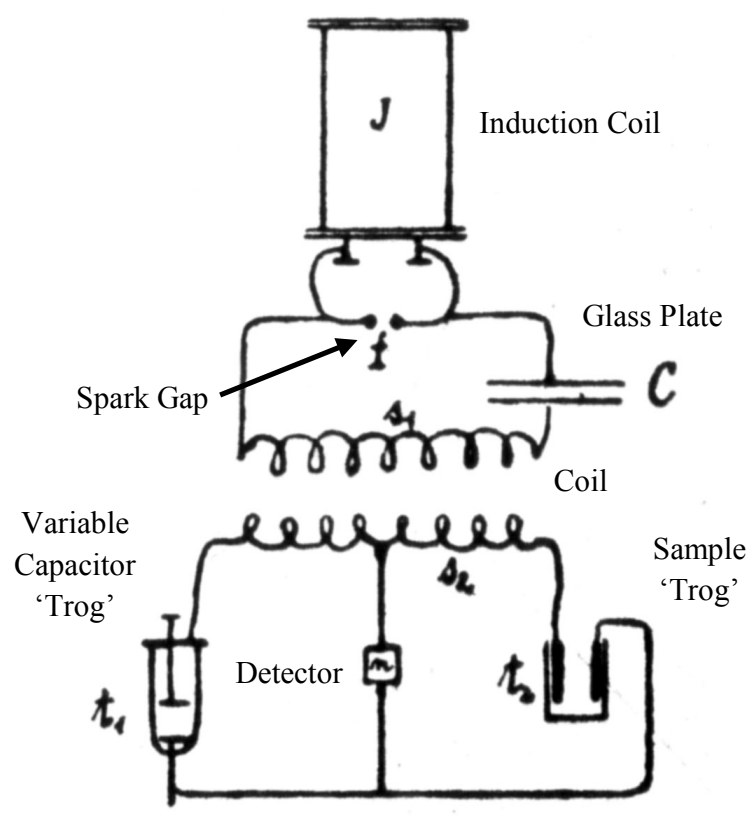

Figure 2. Based on Höber's original drawing [1] his signal generator consisted of an induction coil connected to a spark gap. The frequency of the induced transient oscillating current in the external circuit was determined by the capacitance $C$ of a glass plate and the inductance of a coil wound onto a gas lamp. The conductivity of a trough (trog) of vials to mimic a cell sample, or of a sample of compacted red blood cells, was determined by comparing the damping of the oscillating current due to ion conduction against that of a series of $\mathrm{NaCl}$ solutions. Different forms of detector were tested to optimise the determination of the damping effect.

The signal generator was based on the spark transmitter used in the early days of wireless transmission (valve-based oscillators were not in use until around 1922 [15]). In the circuit shown in Figure 2, the induction coil (120V primary, $30 \mathrm{kV}$ secondary, 17A, made by Siemens \& Halske) charges up the capacitor $C$ until the voltage across it is sufficiently high to break down the insulation of the air in the spark gap. The resulting spark has a comparatively low resistance $(1 \sim 10 \Omega)$ and so effectively completes the oscillatory circuit consisting of the capacitance $C$ in series with the inductance $L$. The capacitor discharges through the spark gap, with the discharge current taking the form of a damped oscillation, until the voltage across the capacitor can no longer maintain the spark. The capacitor then recharges to produce another oscillatory discharge. The time interval between these bursts of oscillation is determined by the $C R$ time constant of the circuit, and the (resonant) frequency of the electric oscillation is

$$
(2 \pi \sqrt{L C})^{-1}
$$

In the 1912 paper [2] the inductance $L$ is estimated to be 1.4 $\mu \mathrm{H}$, and the capacitance $C$ (a $2 \mathrm{~mm}$ thick glass plate with tin foil plates) as $1 \mathrm{nF}$, which gives a resonance frequency of 4.3 MHz (Höber incorrectly estimated a frequency $n$ of 9 $\mathrm{MHz}$, using the relationship:

$$
n=(\pi \sqrt{L C})^{-1}
$$

which defines the angular frequency as $\pi n$ instead of $2 \pi n !)$.

This oscillating circuit was inductively coupled to a modified Wheatstone bridge configuration (capacitors replacing the Kohlrausch slide-wire in the balancing arms) using a primary coil (16 turns) wrapped around a gas light cylinder, and a secondary coil of 66 turns wrapped around a glass pipe into which the primary coil was inserted. Apart from the secondary self-induction coil, the 'receiving' circuit contained two glass troughs (trogs), one acting as a variable plate capacitor filled with water, and the other with fixed silver plate electrodes into which the compacted cell samples or a series of $\mathrm{NaCl}$ solutions were placed. The maximum resonance condition, corresponding to maximum amplitude of the current oscillation, was achieved by slight adjustment of the variable capacitor and with the sample trough containing water. A known volume of compacted cells was then exchanged for the water, and the damping effect on the oscillation magnitude caused by the ionic conduction within this sample was noted. This damping effect was then compared against that produced by a series of different strength $\mathrm{NaCl}$ solutions. At the $\mathrm{MHz}$ frequencies, concentrations between $0.1 \%$ and $0.4 \%$ were found to have an equivalent damping effect as the cell samples (compared to $0.02 \% \mathrm{NaCl}$ at $100 \mathrm{~Hz}$ ). Höber acknowledges the helpful advice of Walter Nernst in the development of this measurement technique. Various forms of detector circuit were tested by Höber, including an inductively coupled circuit containing two $2 \mu \mathrm{F}$ block capacitors connected to a commercial galvanometer (Hartmann \& Braun), and a crystal radio detector.

The electrical properties of compacted samples of blood cells were also simulated by filling glass vials with different concentrations of $\mathrm{NaCl}$ and immersing them into water between the two silver plate electrodes of the sample 'trog' shown in Figure 2. The maximum sensitivity condition was ascertained by noting the micrometer reading of the adjustable capacitor plates used to balance the bridge for different ratios of electrolyte concentrations within and outside the glass vials, and for different concentrations of $\mathrm{NaCl}$ in the variable capacitor 'trog'. He concluded that destroying the protective envelopes of the cells with saponin was equivalent to the salts bound within the glass 
vials escaping from the vials. Although Höber was not satisfied with the sensitivity and accuracy of his measurement techniques, in the summaries of his 1910 and 1912 papers $[1,2]$ he was able to conclude that the basic method he had described was capable of measuring the conductivity of the contents of intact cells.

\section{Höber's 1913 paper [3]}

This paper reports on results obtained using modifications made to the 'receiving' circuit and sample troughs shown in Figure 2. The most important modification was a reduction in the volume of the sample tube from $100 \mathrm{ml}$ to $15 \mathrm{ml}$, which enabled measurements to be made on frog leg muscle. In one modification the sample was contained in a glass chamber made water-tight with a rubber seal, with external brass electrodes. This assembly was connected in parallel to a capacitor composed of rotatable plates, and was found to give an improved sensitivity over his previous methods $[1,2]$ for the tuning to the resonance condition. Further improvement was achieved by connecting the sample holder, in the form of a glass tube with internal platinum wire electrodes, in parallel with the secondary induction coil. Three wires were soldered to this secondary coil so that its inductance could be varied. This modification enabled the resonant frequency to be varied from around $1 \mathrm{MHz}$ to $10 \mathrm{MHz}$.

Höber confirmed the main conclusions of his two previous papers, namely that red blood cells contain an inner conducting electrolyte, implying that they were composed of free rather than organically bound salts, and that the cell membranes possessed limited ion permeability. The average result from 11 experiments was that the internal conductivity of red blood cells was equivalent to a $0.18 \% \mathrm{NaCl}$ solution (minimum $0.11 \%$, maximum $0.3 \%$ ). He noted that this represented about $1 / 3$ to $2 / 3$ of that of the conductivity of blood serum or of Ringer's solution. He reviewed the argument made by others that the reason why blood corpuscles, like many other cells, contain salts in other concentrations to those of their surroundings results from some of them being bound to organic components within the cell. He argues that the experiments he has presented provide proof that at least in blood corpuscles the electrolytes are for the most part to be regarded as being freely detached. Also, the surface of the cell, the plasma skin, acts as an obstacle to the diffusion of salts, so enabling the existing differences in concentration between the free electrolytes outside and those inside to be maintained.

Although he was disappointed by his inability to achieve a high packing density of the frog muscle tissue in the sample tube, he was able to determine that the internal fluid of muscle cells exhibited a conductivity equivalent to that of a $0.1-0.2 \% \mathrm{NaCl}$ solution. The conductivity of the muscle tissue at $\mathrm{MHz}$ frequencies was about five-times greater than that found at $100 \mathrm{~Hz}$ using the Kohlrausch method of measurement. He outlined what was required to achieve more reliable measurements, and made suggestions regarding other systems to study, including turgor pressure of plant cells and the stages of development of fertilised eggs. Through a far-sighted motivation he also reported an attempt to monitor the high-frequency conductivity changes which might accompany the excitation of frog muscle, and he also isolated the nerve from a frog's leg for study. These excursions into what he termed as investigations of bioelectric currents were not conclusive, and he identified this as a promising area for further research.

\section{Later developments}

The implication of an electrically insulating envelope around the conducting interior of a cell did not impact the thinking of physiologists for some time. It was, of course, well appreciated that selective permeability to various ions and chemical species was an essential characteristic of a cell, but whether this reflected a property of the whole mass of a cell or of only its surface remained a puzzle. In 1922 Chambers was able to state that 'the semipermeability of protoplasm, in all probability, depends upon the surface film having properties different from those of the continuous internal protoplasm' [16]. But three years later Brooks [17] can still conclude 'that cells, and in particular red blood cells, are not to be regarded as stable nonconducting particles, but rather as labile and as permeable to electrolytes'. In separate work, Brooks [18] provided the first direct measurement of the conductivity of pure protoplasm (from slime mold), finding it to be equivalent under normal conditions to that of a $0.145 \% \mathrm{NaCl}$ solution. He did not comment that this result agreed well with Höber's result, and so appears to have been ignorant of this earlier work.

However, electrical engineers and biophysicists continued to 'plough their own field'. The next demonstration, after Höber's, of the $\beta$-dispersion exhibited by red blood cells was reported in 1922 by Maurice Philippson (a pioneer of radio broadcasting in Belgium). He described how the magnitude of the specific impedance of the compacted red blood cells fell from a high value $(3,890$ $\left.\Omega \mathrm{cm}^{-3}\right)$ at $1 \mathrm{kHz}$ to a low one $\left(200 \Omega \mathrm{cm}^{-3}\right)$ when extrapolated beyond $3.5 \mathrm{MHz}$ to infinity [19]. He achieved this by measuring the potential across the sample for a range of frequencies, using a tube voltmeter, at the same time as the current. Philippson did not appear to have been aware of Höber's earlier work. The equivalent circuit he envisaged for compacted cells or tissue is shown in Figure 3(a) and consisted of the protoplasm resistance $R$ in series with a parallel combination of the membrane resistance $r$ and capacitance $C$. According to this circuit the impedance at low frequencies (and for direct current) is given as $R+r$, and tends to the value $R$ as the frequency approaches infinity. From Philippson's results for compacted red blood cells we can estimate $R$ and $r$ to have values of $200 \Omega \mathrm{cm}^{-3}$ and $3690 \Omega \mathrm{cm}^{-3}$, respectively [20]. Because Philippson measured the magnitude of the impedance, with no phase 
angle determination, it was not possible for Philippson to determined the membrane capacitance value $C$.

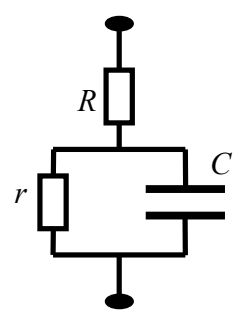

(a)

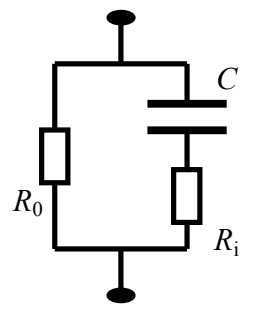

(b)

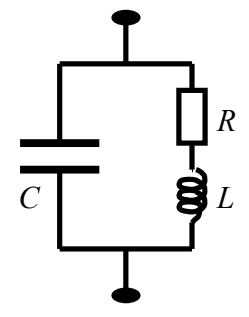

(c)
Figure 3: Equivalent circuits proposed for: (a) tissues and compacted red blood cells by Philippson [20]. $R$ and $r$ are attributed to the cytoplasm and membrane resistance, respectively, and $\mathrm{C}$ to the membrane capacitance; (b) red blood cell suspensions proposed by Fricke \& Morse [5], in which $R_{0}$ is the resistance to current flow around the cell, and $R_{\mathrm{i}}$ is the cytoplasm resistance; (c) the squid giant axon by Cole $\&$ Baker to account for their discovery of the inductive reactance [26]. The values for $R, C$ and $L$ were determined as $1 \mathrm{k} \Omega \mathrm{cm}^{2}, 1 \mu \mathrm{F} / \mathrm{cm}^{2}$ and $0.2 \mathrm{H} \mathrm{cm}^{2}$, respectively.

The next important step was made by Hugo Fricke who determined the specific membrane capacitance of a red blood cell to be $0.8 \mathrm{mFcm}^{-2}$ [21]. This value was independent of the frequency between $3.6 \mathrm{kHz}$ and 4.5 MHz. Fricke does not refer to Höber in his paper, but he was aware of his conclusion regarding the membrane acting as an insulator (Fricke and Morse [5] refer to the modest description given by Höber in his classic book [22]). Fricke would certainly have appreciated that a cell membrane can act as a capacitor only because it is constructed like one namely an insulating dielectric layer sandwiched between two conducting media. Assuming a value of 3 for the dielectric constant of the membrane material, Fricke was able to estimate the thickness of the red blood cell membrane to be $3.3 \mathrm{~nm}$. Although this value turned out to be an underestimate, it was the very first indication of the exquisite thinness of the cell membrane (soon confirmed to be a layer of fatty substances that is two molecules thick [23]). The equivalent circuit used by Fricke and Morse to describe a red blood cell suspension is shown in Figure 3(b). In their application of cable theory to understanding signal transmission along a nerve fibre, Hodgkin and Rushton [24] assumed that the structure of a nonmedullated nerve fibre consisted of a conducting protoplasm and a thin surface membrane of high leakage resistance and large capacitance per unit area. The papers of Höber [1] and Fricke \& Morse [5] were cited as the scientific sources for this assumption, together with that of Curtis \& Cole who had shown that the squid giant axon possessed similar electrical properties to that of the red blood cell [25]. Hodgkin and Rushton [24] also referred to the surprising discovery by Cole \& Baker [26] that the squid axon exhibited an inductive reactance below $150 \mathrm{~Hz}$ (see Figure 3(c) for the proposed equivalent circuit). Following the development of the patch-clamp technique by Cole [27] an understanding of the implications of this inductive element in the membranes of nerve cells could begin, leading to the elucidation of nerve pulses in terms of 'reversible alterations in sodium and potassium permeability arising from changes in membrane potential' [28] and the award of the Nobel Prize to Hodgkin and Huxley.

The three papers [1-3] discussed here represent Höber's only direct contributions to the electrical properties of cells. This reflects the fact that his research interests were very broad and included studies of: intestinal resorption; mechanisms of catalysis; cell membrane permeability; the concentration of hydroxyl ions in blood; the mechanism of narcosis and its influence upon membrane permeability; vital staining of cells; the secretion of urine; the physiological properties of colloids, and the effects of ions upon the resting potential of nerve and muscle [29]. All of this and much more, was included in his influential book [22], which enjoyed seven editions from 1902 to 1926, growing from 300 to 900 pages in the process. This was essential reading (in German) for those who wished to interpret the behaviour of cells and living organisms in terms of physico-chemical principles. A completely revamped version (in English) appeared in 1945 with four co-authors, and in its review by Davson [30] the remark is made that 'It may well be said that the wisdom and benevolence exhibited by the University of Pennsylvania, when they offered Höber an intellectual home, have borne a rich harvest'. This was a subtle way of referring to the fact that Höber did not lead a trouble-free life. In 1931, as rector of the University of Kiel, he chaired a university disciplinary court that expelled six pro-Nazi students on assault charges. As a consequence he was forced to retire in 1933 [29]. In 1934, after spending a few months at University College, London, he accepted a visiting professorship at the School of Medicine, University of Philadelphia. Before his expulsion from Germany in 1934, he and his wife Josephine made several visits to the Marine Biological Laboratory (MBL) at Woods Hole, Massachusetts, to conduct research together there. From 1936 to 1949 he taught summer courses in physiology at the MBL. Rudolf Höber was born in Stettin, Germany, on 27 December 1873 - he died on 5 September 1953 in Philadelphia. A new Institute of Physiology was created at the University of Kiel - named the Rudolf Höber Haus.

\section{Acknowledgements}

Rudolf Höber and others whose works have been cited here (Baker, Brooks, Cole, Curtis, Fricke and Hodgkin) spent various periods conducting research at the MBL, Woods Hole. We thank the staff of the MBLWHOI Library, especially Matthew Person, for providing access to archived material and some of the original publications used in preparing this article. 


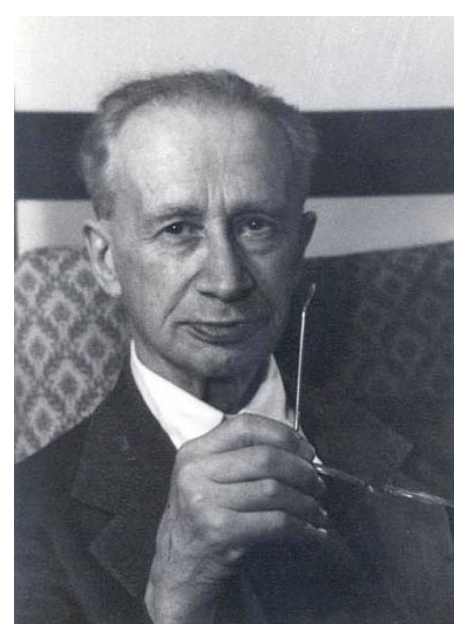

Rudolf Höber, ca. 1950. (Reproduced with permission of the American Philosophical Society.)

\section{References}

1. R. Höber, Eine Methode, die elektrische Leitfähigkeit im Innern von Zellen zu messen, Pflügers Archiv Physiologie des Menschen und der Tiere, 133: 237-253 (1910). http://dx.doi.org/10.1007/BF01680330

2. R. Höber, Ein zweites Verfähren die elektrische Leitfähigkeit im Innern von Zellen zu messen, Pflügers Archiv Physiologie des Menschen und der Tiere, 148: 189-221 (1912). http://dx.doi.org/10.1007/BF01680784

3. R. Höber, Messungen der inneren Leitfähigkeit von Zellen, Pflügers Archiv Physiologie des Menschen und der Tiere, 150: 15-45 (1913). http://dx.doi.org/10.1007/BF01681047

4. H P Schwan, Electrical properties of tissue and cell suspensions, in: 'Advances in Biological and Medical Physics', J H Lawrence and C A Tobias, Eds., Vol. V., pp 147-209, Academic Press Inc., New York (1957).

5. H. Fricke and S. Morse, The electrical resistance and capacity of blood for frequencies between 800 and 41/2 million cycles, J. Gen. Physiol. 9: 153-167 (1925). http://dx.doi.org/10.1085/jgp.9.2.153

6. H. Fricke and H. J. Curtis, The electric impedance of hemolyzed suspensions of mammalian erythrocytes, J. Gen. Physiol. 18: 821-836 (1935). http://dx.doi.org/10.1085/jgp.18.6.821

7. S. Grimnes and Ø. G. Martinsen, Bioimpedance and bioelectricity basics, 2. ed., Academic Press, San Diego, 2008.

8. M. Planck, Über die Potentialdifferenz zwischen zwei verdünnten Lösungen binärar Elektrolyte, Ann. Physik u. Chem. 40: 561-576 (1890).

9. W. Nernst, Zur Theorie der elektrischen Reizung, Nachrichten von der Königl. Gesellschaft der Wissenschaften zu Göttingen, 104-108 (1899).

10. E. Overton, Über die allgemeinen osmotischen Eigenschaften der Zelle, ihre vermutlichen Ursachen und ihre Bedeutung für die Physiologie, Vjochr. Naturforschung Ges. Zuriich, 44: 88-135 (1899)

11. G. N. Stewart, The conditions that underlie the pecularities in the behaviour of the coloured blood-corpuscles to certain substances, J. Physiol. 26: 470-496 (1901).
12. J. Bernstein, Untersuchungen zur Thermodynamik der bioelektrischen Ströme, Arch. Ges. Physiol. 92: 521-562 (1902). http://dx.doi.org/10.1007/BF01790181

13. F. Kohlrausch and W. A. Nippoldt, Über die Gültigkeit der Ohmschen Gesetze für Electrolyte und eine numerische Bestimmung des Leitungswiderstanes der verdünnten Schwefelsaure durch alternierende Ströme, Ann. Phyik. 138: 280-298; 370-390 (1869).

14. F. Kohlrausch, Über die Wirkung der Polarisation auf alternierende Ströme und über einen Sinusinduktor, Ann. Physik. 143: 290-303 (1874).

15. M. F. Van Aalst, On the maintenance of electric oscillations by a three-electrode valve, Comptes Rendus, 1397-1399 (Dec. 26, 1922).

16. R. Chambers, A micro-injection study on the permeability of the starfish egg, J. Gen. Physiol. 5: 189-193 (1922). http://dx.doi.org/10.1085/jgp.5.2.189

17. S. C. Brooks, Conductivity as a measure of the permeability of suspended cells, J.Gen. Physiol. 7 (3): 349-362 (1925). http://dx.doi.org/10.1085/jgp.7.3.349

18. S. C. Brooks, The electrical conductivity of pure protoplasm, J.Gen. Physiol. 7 (3): 327-330 (1925). http://dx.doi.org/10.1085/jgp.7.3.327

19. M. Philippson, Sur la résistance électrique des cellules et des tissus, Compt. Rend. Soc. Biol. 83: 1399-1402 (1920).

20. M. Philippson, Les lois de la résistance électrique des tissus vivants, Bull. Acad. Roy. Belgique 7 (Ser. 5): 387-403 (1921).

21. H. Fricke, The electric capacity of suspensions with special reference to blood, J. Gen Physiol. 9: 137-152 (1925). http://dx.doi.org/10.1085/jgp.9.2.137

22. R. Höber, Physikalische Chemie der Zelle und der Gewebe, Leipsic, p. 460 (1922).

23. E. Gorter and F. Grendel, On bimolecular layers of lipoids on the chromocytes of the blood, J. Exp. Medicine 41: 439-443 (1925). http://dx.doi.org/10.1084/jem.41.4.439

24. A. L. Hodgkin and W. A. H. Rushton, The electrical constants of a crustacean nerve fibre, Proc. Roy. Soc. London, Series B, Biological Sciences, 133 (873): 444-479 (1946).

25. H. J. Curtis and K. S. Cole, Transverse electric impedance of the squid giant axon, J. Gen. Physiol. 21(6): 757-765 (1938). http://dx.doi.org/10.1085/jgp.21.6.757

26. K. S. Cole and R. F. Baker, Longitudinal impedance of the squid giant axon, J.Gen. Physiol. 24 (3): 771-778 (1941). http://dx.doi.org/10.1085/jgp.24.6.771

27. K. S. Cole, Dynamic electrical characteristics of the squid axon membrane, Archives des Sciences Physiologiques 3: 253-258 (1949)

28. A. L. Hodgkin and A. F. Huxley, A quantitative description of membrane current and its application to conduction and excitation in nerve, J. Physiol. 117: 500-544 (1952).

29. W. R. Amberson, Rudolf Höber: His life and scientific work, Science 120 (3110): 199-201 (1954). http://dx.doi.org/10.1126/science.120.3110.199

30. H. Davson, Physical chemistry of cells and tissues, Quarterly Rev. Biol. 21 (3): 280-281 (1946). http://dx.doi.org/10.1086/395328 